\title{
Praperadilan Terhadap Penetapan Status Tersangka Tindak Pidana Korupsi oleh Komisi Pemberantasan Korupsi
}

\author{
Claudia Permata Dinda, Usman, Tri Imam Munandar \\ Fakultas Hukum, Universitas Jambi \\ Author's email correspondence: claudiadinda58@gmail.com
}

\begin{abstract}
ABSTRAK
Praperadilan yang diatur dalam KUHAP menjamin perlindungan HAM dan aparat penegak hukum dalam menjalankan tugas dan kewenangannya secara konsekwen. Lembaga praperadilan telah menciptakan mekanisme kontrol sebagai lembaga yang berwenang melakukan pengawasan terhadap kinerja aparat penegak hukum dalam menjalankan tugasnya guna tercipta proses peradilan pidana yang baik. Terkait dengan penegakan hukum dan pemberantasan korupsi, Komisi Pemberantasan Korupsi merupakan lembaga yang diamanatkan oleh undang-undang dengan wewenangnya untuk menetapkan status tersangka guna proses penyelidikan dan penyidikan tindak pidana korupsi. Penelitian ini bertujuan untuk mengetahui akibat dari perluasan objek praperadilan atas penetapan status tersangka terhadap KUHAP dan mengetahui akibat dari perluasan objek praperadilan terhadap penetapan status tersangka tindak pidana korupsi oleh KPK. Metode penelitian yang digunakan dalam penelitian ini adalah metode penelitian yuridis normatif melalui pendekatan konseptual, pendekatan peraturan perundangundangan dan pendekatan kasus. Sebelumnya, sah atau tidaknya penetapan status tersangka oleh KPK bukan merupakan objek praperadilan, namun melalui Putusan Mahkamah Konstitusi Nomor 21/PUU-XII/2014 praperadilan telah berwenang memeriksa sah atau tidaknya penetapan status tersangka. Hal ini menjadi sebuah pembaharuan dalam Hukum Acara Pidana di Indonesia.
\end{abstract}

Kata Kunci: Praperadilan;

Korupsi; Komisi

Pemberantasan Korupsi

\section{ARTICLE HISTORY}

Submission: 2020-06-08

Accepted: 2020-10-07

Publish: 2020-10-10

KEYWORDS:

Pretrial, Corruption, Corruption Eradication Commission
ABSTRACT

Pretrial regulated in the Criminal Procedure Code guarantees the protection of human rights and law enforcement officers in carrying out their duties and authorities consistently. The pretrial institution has created a control mechanism as an institution authorized to supervise the performance of law enforcement officers in carrying out their duties in order to create a good criminal justice process. This study aims to determine the effects of the expansion of pretrial objects over the determination of the status of suspects against the Criminal Procedure Code and to determine the consequences of expanding pretrial objects to determine the status of suspected criminal acts of corruption by the KPK. The research method used in writing this thesis is a normative juridical research method through the conceptual approach, the statutory approach and the case approach. Previously, the KPK was not a pretrial object or not, but through the Constitutional Court Decision Number 21 / PUU-XII / 2014 the pretrial had the authority to examine whether or not the status of the suspect was determined. This has become a renewal in the Indonesian Criminal Procedure Code 


\section{A. Pendahuluan}

Korupsi di Indonesia telah menjangkiti sistem kekuasaan secara terstruktur, sistematik dan masif. Penyelenggaraan kekuasaan kemudian tidak dapat sepenuhnya mengabdi pada kepentingan rakyat karena terdistorsi dengan maraknya perilaku koruptif. Hal inilah yang menyebabkan kesejahteraan sulit terwujud di negeri yang dikenal gemah ripah loh jinawi dengan kekayaan sumber daya alam yang melimpah ini. Kondisi ini sesungguhnya telah disadari oleh Bangsa Indonesia. Oleh karena itu, sejak reformasi bergulir, pemberantasan korupsi menjadi salah satu agenda prioritas. Bahkan hampir semua agenda reformasi, baik langsung maupun tidak langsung, ditujukan untuk meminimalisasi potensi korupsi. ${ }^{1}$ Pemberantasan korupsi secara menyeluruh bukan hanya sekedar impian bagi setiap orang, namun tentu saja hal tersebut tidak serta merta dapat dilaksakan seperti membalikkan telapak tangan.

Hasil Penelitian Masyarakat Transparansi Internasional yang merilis tentang Indeks Persepsi Korupsi (IPK) atau disebut juga Corruption Perception Index (CPI) memang menunjukkan adanya perbaikan dari tahun ke tahun, namun sangat lambat. Peringkat dinegara-negara yang diteliti oleh lembaga tersebut masih terbilang rendah, terutama jika dibandingkan dengan negara-negara tetangga seperti Singapura dan Brunei Darussalam. Singapura dan Brunei Darussalam memiliki IPK tinggi yakni 8,6 dan 6,0. Skor IPK pada tahun 2013 masih merujuk pada angka 3,2. Skor yang sama dengan perolehan pada tahun 2012. Kendati begitu, peringkat Indonesia naik dari posisi 118 pada tahun 2012 menjadi 114 pada tahun 2013.2 Selanjutnya Organisasi Transparansi Internasional mengeluarkan laporan Tahunan Indeks Persepsi Korupsi pada Januari 2017 yang menunjukkan bahwa meski perolehan skor Indonesia naik namun berdasarkan laporan tahunan atas hasil upaya pemberantasan korupsi yang dilakukan 176 negara, rangking Indonesia turun pada peringkat ke $90 .{ }^{3}$

Di dunia internasional, tindak pidana korupsi merupakan masalah yang sangat serius, karena tindak pidana korupsi dapat membahayakan stabilitas dan keamanan masyarakat serta negara, membahayakan pembangunan sosial dan ekonomi masyarakat, politik, bahkan dapat pula merusak nilai-nilai demokrasi serta moralitas bangsa karena dapat berdampak membudayanya tindak pidana korupsi tersebut.4 Salah satu perwujudan kepedulian dunia internasional terhadap dampak dari korupsi adalah disepakatinya United Nations Convention Against Corruption pada tahun 2003 atau Konvensi Perserikatan Bangsa-bangsa Anti Korupsi. Konvensi ini kemudian diratifikasi oleh Indonesia melalui Undang-undang Nomor 7 Tahun 2006. Salah satu poin dari konsideran undang-undang tersebut adalah: Bahwa tindak pidana korupsi tidak lagi merupakan masalah lokal, akan tetapi merupakan fenomena transnasional yang mempengaruhi seluruh masyarakat dan perekonomian sehingga perlu adanya kerjasama internasional untuk pencegahan dan pemberantasannya termasuk pemulihan atau pengembalian aset-aset hasil tindak pidana korupsi.

1 Ikhwan Fahrojih, Hukum Acara Pidana Korupsi, Setara Press, Malang ,2016, hlm. 1.

2 Imam Anshori Saleh, Korupsi, Terorisme, dan Narkoba (Upaya Melawan Kejahatan Luar Biasa yang Sistematis), Setara Press, Malang, 2017, hlm. 2.

3 https://www.google.co.id/amp/s/www.voaindonesia.com/amp/3692750.html, diakses pada 24 Oktober 2017 Pukul 22.05 Wib.

4 Ibid, hlm. 7. 
Salah satu upaya pemberantasan tindak pidana korupsi di Indonesia telah dibuktikan oleh pemerintah dengan memberlakukan Undang-Undang Nomor 31 Tahun 1999 Tentang Pemberantasan Tindak Pidana Korupsi yang kemudian telah diubah menjadi Undang-Undang Nomor 20 Tahun 2001 Tentang Perubahan atas Undang-Undang Nomor 31 Tahun 1999 Tentang Pemberantasan Tindak Pidana Korupsi dan juga dibentuknya sebuah lembaga Komisi Pemberantasan Korupsi yang dibentuk berdasarkan Undang-Undang Nomor 30 Tahun 2002 Tentang Komisi Pemberantasan Tindak Pidana Korupsi (selanjutnya disebut UndangUndang KPK). Status hukum komisi ini secara tegas ditentukan sebagai lembaga Negara yang dalam melaksanakan tugas dan wewenangnya bersifat independen dan bebas dari pengaruh kekuasaan manapun. Pembentukan komisi ini bertujuan untuk meningkatkan daya guna dan hasil guna upaya pemberantasan tindak pidana korupsi yang sudah berjalan sejak sebelumnya. ${ }^{5}$

Jika menelaah lebih lanjut mengenai tindak pidana korupsi tentunya tidak akan terlepas pada pelaku tindak pidana korupsi. Mulai dari tahap penyelidikan dan penyidikan yang dengan mengumpulkan bukti guna menemukan tersangka selanjutnya tahap penuntutan yang menghadapkan terdakwa kemuka persidangan untuk diperiksa dan diadili. Keseluruhan proses tersebut akan berujung pada status terpidana atau narapidana dengan putusan hakim yang menyatakan bahwa pelaku tersebut terbukti bersalah. Pasal 1 butir 14 Undang-Undang Nomor 8 Tahun 1981 Tentang Kitab Undang-Undang Hukum Acara Pidana (KUHAP) menyebutkan bahwa "Tersangka adalah seseorang yang karena perbuatannya atau keadaannya, berdasarkan bukti permulaan patut diduga sebagai pelaku tindak pidana."

Terkait dengan penetapan status tersangka tindak pidana sering terjadi pro dan kontra dari berbagai pihak. Penetapan status tersangka adalah kewenangan dari penyidik, sebagaimana yang telah digariskan di dalam KUHAP. Penyelidikan dalam KUHAP diartikan sebagai proses untuk menemukan dan mengungkap adanya tindak pidana pada suatu peristiwa tertentu. Proses penyelidikan tersebut diikuti dengan proses penyidikan yang bertujuan untuk mencari serta mengumpulkan bukti, yang dengan bukti tersebut akan membuat terang suatu perkara guna menemukan tersangkanya. Manakala dalam hal penyidik menemukan bukti permulaan yang cukup, maka seseorang yang diduga telah melakukan tindak pidana dapat ditetapkan sebagai tersangka.

Beranjak dari penetapan status tersangka oleh penyidik yang diatur melalui KUHAP, maka tugas penetapan status tersangka juga dimiliki oleh penyidik Komisi Pemberantasan Korupsi (selanjutnya disebut KPK) yang secara tegas telah diatur dalam Undang-Undang KPK, sepanjang tidak diatur dalam UU KPK dan UndangUndang Pemberantasan Tindak Pidana Korupsi, maka kembali pada aturan-aturan yang ada dalam KUHAP. Pasal 1 butir 14 KUHAP merumuskan bahwa "Tersangka adalah seseorang yang karena perbuatannya atau keadaannya, berdasarkan bukti permulaan, patut diduga sebagai pelaku tindak pidana." Sementara di UndangUndang Pemberantasan Tindak Pidana Korupsi dan Undang-Undang KPK tidak ada satupun pasal yang menjelaskan mengenai penetapan tersangka. Selanjutnya ketika berbicara mengenai bagaimana kewenangan KPK dalam hal menetapkan

5 Jimly Asshiddiqie, Perkembangan \& Konsolidasi Lembaga Negara Pasca Reformasi, Sinar Grafika, Jakarta, 2012, hlm. 194. 
status tersangka tindak pidana korupsi maka hal ini tidak terlepas dari Praperadilan sebagai salah satu upaya yang dapat ditempuh untuk menegakkan hukum dan melindungi hak-hak tersangka dalam tingkat penyidikan dan penuntutan.

Definisi praperadilan berdasarkan Pasal 1 butir 10 KUHAP adalah bahwa:

Praperadilan merupakan wewenang dari pengadilan negeri untuk memeriksa dan memutus tentang sah atau tidaknya suatu penangkapan dan/atau penahanan atau permintaan tersangka atau keluarganya atau pihak lain atau kuasa tersangka; sah atau tidaknya penghentian penyidikan atau penghentian penuntutan atas permintaan demi tegaknya hukum dan keadilan; serta permintaan ganti kerugian atau rehabilitasi oleh tersangka atau keluarganya atau pihak lain atau kuasanya yang perkaranya tidak diajukan ke pengadilan.

Praperadilan merupakan hal baru dalam dunia peradilan Indonesia. Praperadilan merupakan salah satu lembaga baru yang diperkenalkan KUHAP ditengah-tengah kehidupan penegakan hukum. ${ }^{6}$ Mahkamah Konstitusi (MK) pada tanggal 28 April 2015 lalu telah mengabulkan sebagian pengujian Undang-Undang Nomor 8 Tahun 1981 tentang Kitab Undang-Undang Hukum Acara Pidana (KUHAP). Berdasarkan Amar Putusan Mahkamah Konstitusi Nomor 21/PUUXII/2014, Mahkamah Konstitusi telah menetapkan perluasan objek praperadilan yaitu mengenai sah atau tidaknya penetapan tersangka, penggeledahan dan penyitaan. Mahkamah Konstitusi menjadikan penetapan tersangka sebagai salah satu objek praperadilan yang sebelumnya tidak diatur dalam KUHAP. ${ }^{7}$

Pengajuan permohonan gugatan praperadilan dalam hal penetapan tersangka dibatasi secara limitatif oleh Pasal 1 butir 10 juncto Pasal 77 huruf a KUHAP. Walaupun terdapat pembatasan secara limitatif terhadap permohonan gugatan praperadilan, namun tidak dapat dipungkiri bahwa penetapan status tersangka terhadap seseorang merupakan bagian dari proses penyidikan yang didalamnya kemungkinan terdapat tindakan sewenang-wenang dari penyidik yang termasuk perampasan terhadap hak asasi seseorang. Mahkamah Konstitusi berpendapat, dimasukkannya keabsahan penetapan tersangka sebagai objek pranata praperadilan adalah agar perlakuan terhadap seseorang dalam proses pidana memperhatikan tersangka sebagai manusia yang mempunyai harkat, martabat dan kedudukan yang sama di hadapan hukum. ${ }^{8}$

Jika kembali mengamati sepanjang tahun 2017, telah banyak pihak-pihak yang mengajukan gugatan praperadilan terkait sah atau tidaknya penetapan status tersangka. Beberapa di antaranya ditolak dan tidak sedikit pula yang diterima oleh Hakim tunggal praperadilan. Adapun beberapa contoh gugatan praperadilan terhadap sah atau tidaknya status tersangka yang ditolak adalah Permohonan Pembatalan Status Tersangka Tindak Pidana Korupsi yang diajukan oleh Miryam S

$6 \quad$ M. Yahya Harahap, Pembahasan Permasalahan dan Penerapan KUHAP Pemeriksaan Sidang Pengadilan, Banding, Kasasi dan Peninjauan Kembali Edisi Kedua, Sinar Grafika, Jakarta, 2012, hlm. 1.

7 Wanda Rara Farezha, Edy Rifa'I, Gunawan Jatmiko, Abstrak Analisis Putusan Hakim Praperadilan dalam Perkara Tindak Pidana Korupsi (Studi Putusan Praperadilan Nomor 14/Pid.Pra/2016/PN.Tjk), hlm. 1.

8 http://www.mahkamahkonstitusi.go.id/index.php?page=web.Berita\&id=10796, diakses pada 4 Desember 2017, Pukul 11.27 wib. 
Haryani, Permohonan Pembatalan Status Tersangka dalam Kasus Dugaan Pengancaman terhadap Kepala Subdirektorat Penyidik Jaksa Agung Muda Pidana Khusus Yulianto melalui Media Elektronik yang diajukan oleh Hary Tanoe, dan lainlain.

Namun, disamping banyaknya permohonan gugatan praperadilan yang ditolak, terdapat beberapa kasus dikabulkannya permohonan pembatalan status tersangka tindak pidana korupsi, salah satu contohnya adalah pembatalan status tersangka terhadap permohonan gugatan praperadilan yang diajukan oleh Budi Gunawan yang kemudian menimbulkan kontroversi tersendiri dikalangan masyarakat dan juga menyebabkan adanya perubahan yang bersifat fundamental terhadap peraturan perundang-undangan terkait adanya perluasan kewenangan praperadilan yang dilakukan oleh Hakim pada saat itu. Belum hilang dalam ingatan masyarakat terkait kontroversi putusan praperadilan terkait pembatalan status tersangka terhadap Budi Gunawan, salah satu kasus gugatan praperadilan terbaru dan menarik perhatian masyarakat adalah penetapan status tersangka terhadap Setya Novanto melalui Putusan Praperadilan Nomor 97/Pid.Prap/2017/PN.Jkt.Sel yang berakibat pada pembatalan penetapan status tersangka tindak pidana korupsi. Munculnya putusan praperadilan yang membatalkan status tersangka tindak pidana korupsi terhadap Setya Novanto menimbulkan fenomena tersendiri dikalangan masyarakat, sebagian pihak memuji keberadaan lembaga praperadilan sebagai salah satu bentuk upaya melindungi Hak Asasi Manusia namun disisi lain lembaga praperadilan pun dimanfaatkan sebagai tempat berlindung oleh para tersangka tindak pidana korupsi yang tidak bertanggungjawab untuk melepaskan diri dari jeratan hukum.

\section{B. Metode Penelitian}

Tipe penelitian ini adalah yuridis normatif, melalui pendekatan konseptual, pendekatan peraturan perundang-undangan dan pendekatan kasus dengan mengkaji aturan hukum tentang praperadilan yang dimuat dalam KUHAP dan Putusan Mahkamah Konstitusi Nomor 21/PUU-XII/2014, Mahkamah Konstitusi terkait penetapan perluasan objek praperadilan yaitu mengenai sah atau tidaknya penetapan tersangka, penggeledahan dan penyitaan.

\section{PEMBAHASAN}

\section{Akibat dari Perluasan Objek Praperadilan atas Penetapan Status Tersangka terhadap Pembaharuan Kitab Undang-Undang Hukum Acara Pidana}

Kehadiran lembaga praperadilan dalam Hukum Acara Pidana di Indonesia merupakan babak baru dalam rangka menciptakan dan mewujudkan peradilan pidana yang lebih baik dan lebih manusiawi. Salah satu hukum positif yang berlaku saat ini adalah Undang-Undang Nomor 8 Tahun 1981 Tentang Kitab Undang-Undang Hukum Acara Pidana (KUHAP). Hukum acara pidana dibuat dengan tujuan untuk mencari kebenaran dan keadilan melalui pedomanpedoman yang tertulis dan memberikan jaminan terhadap penegakan hukum pidana materil untuk mendapatkan kepastian hukum. Hal ini tentu saja merupakan amanat yang sangat berkesesuaian dengan Pasal 1 ayat (3) Undang-Undang Dasar NRI Tahun 1945 yang menyatakan bahwa Negara Indonesia adalah Negara Hukum, yang berarti bahwa hukum di negara ini 
ditempatkan pada posisi strategis di dalam konstelasi ketatanegaraan. Penjelasan umum KUHAP telah menyebutkan bahwa KUHAP adalah "bersifat nasional sehingga wajib didasarkan pada falsafah/pandangan hidup bangsa dan dasar negara." Maka sudah seharusnya ketentuan materi pasal atau ayat dalam undang-undang ini mencerminkan perlindungan terhadap hak asasi manusia.

Andi Hamzah dalam bukunya Hukum Acara Pidana Indonesia menyatakan bahwa "Hukum Acara Pidana memiliki ruang lingkup yang lebih sempit yaitu dimulai dari mencari kebenaran, penyelidikan, penyidikan dan berakhir pada pelaksanaan pidana (eksekusi) oleh Jaksa."9 Berdasarkan pendapat tersebut dapat ditarik kesimpulan bahwa antara KUHP dan KUHAP memiliki perbedaan, yakni KUHAP adalah hukum pidana formal atau Hukum Acara Pidana yang berisi bagaimana cara untuk menegakkan hukum pidana materiil. Tegasnya, KUHAP berisi tata cara atau prosedur diprosesnya seseorang yang melakukan tindak pidana, sedangkan KUHP merupakan hukum pidana materiil yang berisikan aturan atau kaidah hukum yang bersifat mengikat pada setiap orang.

Walaupun KUHAP tidak memberikan pengertian yuridis tentang Hukum Acara Pidana, namun pada hakikatnya Hukum Acara Pidana memuat kaidah-kaidah yang mengatur tentang penerapan ataupun tata cara antara lain mengenai penyelidikan, penyidikan, penuntutan, pemeriksaan dipersidangan, pengambilan keputusan pengadilan, upaya hukum dan pelaksanaan penetapan atau putusan pengadilan didalam upaya mencari dan menemukan kebenaran materiil.

Belumlah cukup apabila hukum acara pidana yang telah memberikan keserasian antara hak asasi seseorang dengan kepentingan suatu proses pidana, akan tetapi juga diperhatikan hubungannya dengan sistem peradilan pidana dalam keseluruhannya. Hukum acara pidana adalah "Sebagian dari komponen dalam suatu sistem peradilan pidana dalam suatu negara, dan setiap negara mempunyai sistem yang berbeda sehingga berbeda pula efektivitas pencegahan kejahatannya."10

Terkait praperadilan telah diatur sedemikian rupa dalam KUHAP pada Bab ke-X mengenai kewenangan pengadilan untuk mengadili, bagian kesatu yang memuat pasal-pasal tentang Praperadilan, yakni dimulai dari Pasal 77 sampai dengan Pasal 83. Selain itu, Pasal 1 butir 10 KUHAP juga menegaskan bahwa:

Praperadilan adalah wewenang pengadilan negeri untuk memeriksa dan memutus menurut cara yang diatur dalam undang-undang ini, tentang:

a. Sah atau tidaknya suatu penangkapan dan atau penahanan atas permintaan tersangka atau keluarganya atau pihak lain atas kuasa tersangka;

b. Sah atau tidaknya penghentian penyidikan atau penghentian penuntutan atas permintaan demi tegaknya hukum dan keadilan;

9 Andi Hamzah, Hukum Acara Pidana Indonesia Edisi Revisi, Sinar Grafika, Jakarta, 2004, hlm. 2.

10 Op.cit, hlm. 14-15. 
c. Permintaan ganti kerugian atau rehabilitasi oleh tersangka atau keluarganya atau pihak lain atas kuasanya yang perkaranya tidak diajukan ke pengadilan.

Berdasarkan Pasal 1 butir 10 KUHAP tersebut disimpulkan bahwa pada dasarnya setiap upaya paksa (enforcement) dalam penegakan hukum mengandung nilai hak asasi manusia yang sangat kental. Oleh karenanya, hak asasi tersebut harus dilindungi dengan seksama dan juga hati-hati, sehingga perampasan atasnya tetap sesuai dengan aturan yang berlaku dan juga tentu tetap sesuai dengan teori perlindungan hukum yang sangat mengedepankan hak asasi manusia dalam setiap proses penegakan hukum termasuk dalam hal pelaksanaan upaya paksa.

Seperti dinyatakan dalam KUHAP bahwa: ${ }^{11}$

Praperadilan dimaksudkan untuk kepentingan pengawasan terhadap perlindungan hak-hak tersangka/terdakwa, maka tentunya hak yang dilindungi tersebut bukan saja terhadap suatu penangkapan dan penahanan saja, melainkan keseluruhan dari upaya paksa, karena upaya paksa adalah suatu tindakan yang akan mengurangi hak dari tersangka/terdakwa, sehingga perlu dilakukan suatu pengawasan terhadap pelaksanaannya.

Oleh sebab itu, apabila ditinjau dari maksud diselenggarakannya praperadilan dalam KUHAP, maka semestinya lembaga Praperadilan inipun berwenang untuk mengawasi bukan saja terhadap penangkapan serta penahanan saja, akan tetapi meliputi keseluruhan dari upaya paksa. Praperadilan berfungsi sebagai kontrol bagi penegakan hukum atas aparat penegakan hukum itu sendiri guna melindungi hak-hak dari tersangka atau terdakwa. Pada implementasi, fungsi adanya lembaga Praperadilan adalah sebagai media kontrol atau sebagai pengingat bagi aparat penegak hukum dalam menjalankan kewenangannya sehingga tidak melakukan tugas dan fungsinya dengan sewenang-wenang atau diluar kesewenangannya. Sedangkan peranan praperadilan adalah dalam rangka penegakan aturan yang ada untuk melindungi hak dari tersangka. Tidak terlalu berbeda antara fungsi dan peranan Praperadilan. Jika fungsi dari praperadilan adalah sebagai kontrol bagi penegakan hukum atas aparat penegakan hukum itu sendiri untuk melindungi hak-hak dari tersangka atau terdakwa, peranan Praperadilan justru muncul dalam rangka penegakan aturan yang ada untuk melindungi hak dari tersangka.

Praperadilan diatur oleh KUHAP untuk menjamin perlindungan hak asasi manusia dan agar para aparat penegak hukum menjalankan tugasnya secara konsekwen, efektif dan efisien. Dengan bekerja secara efisien untuk menanggulangi kejahatan tidak berarti dengan demikian harus mengurangi hak

11 Ibid, hal. 41. 
asasi manusia seseorang, sehingga dengan adanya lembaga praperadilan, KUHAP telah menciptakan mekanisme kontrol yang berfungsi sebagai lembaga yang berwenang untuk melakukan pengawasan terhadap bagaimana kinerja aparat penegak hukum dalam menjalankan tugas dan fungsinya dalam Peradilan pidana sebagai implementasi dari pelaksanaan sistem peradilan pidana yang terpadu. Berdasarkan fakta yang terjadi, terlihat jelas bahwa praperadilan mempunyai peranan yang besar dalam rangka penegakan hukum pidana di Indonesia. Buktinya adalah dengan adanya praperadilan, memberikan ruang kepada pihakpihak yang dirugikan dalam proses peradilan pidana di Indonesia untuk menuntut kembali hak-haknya yang dirugikan. Ketentuan ini jelas sesuai dengan prinsip yang terkandung dalam KUHAP yang dijiwai prisip perlindungan terhadap harkat dan martabat manusia yang juga dilindungi dalam UndangUndang Dasar Negara Republik Indonesia Tahun 1945 khusus Pasal 28 tentang Hak Asasi Manusia.

Oleh karena itu, dapat disimpulkan bahwa dasar dari adanya lembaga Praperadilan ini adalah suatu cerminan dari pelaksanaan asas praduga tidak bersalah (presumption of innocent) sehingga tiap orang yang diajukan sebagai terdakwa telah melalui proses awal yang wajar dan mendapat perlindungan harkat dan martabatnya sebagai manusia dan juga sebagai lembaga yang melakukan pengawasan horizontal atas tindakan upaya paksa yang dilakukan terhadap tersangka selama ia berada dalam pemeriksaan penyidikan atau penuntutan, agar tindakan yang dilakukan itu benar-benar sesuai dengan aturan yang berlaku.

Terlepas dari kewenangan Hakim Praperadilan dalam hal menguji sah atau tidaknya suatu penangkapan dan penahanan, maka Praperadilan sudah menunjukkan adanya Hakim yang telah berperan aktif dalam fase pemeriksaan pendahuluan. Hal ini menjadi arti bahwa dengan adanya Praperadilan maka sistem peradilan pidana yang dianut oleh negara Indonesia telah menjadi suatu pengawasan disamping secara vertikal maupun horizontal.

Kewenangan praperadilan yang diatur dalam Pasal 1 butir 10 dan Pasal 77 KUHAP adalah "Sebagai salah satu kewenangan Pengadilan secara horizontal atas penerapan upaya paksa oleh Polisi, Jaksa dan KPK yang meliputi sah atau tidaknya Penangkapan, Penahanan, Penghentian Penyidikan atau Penghentian Penuntutan". Sehingga pihak ketiga yang merasa haknya dirugikan dapat memperjuangkan hak-haknya tersebut pada lembaga Praperadilan. 
Seiring berjalannya waktu, seperti pendapat yang dikemukakan oleh Von Savigny bahwa "Hukum mengikuti perkembangan masyarakat dan bersifat organis, diluar dari perkembangan masyarakat tidak terdapat hukum."12 Disimpulkan bahwa hukum bersifat dinamis, sehingga dapat berubah-ubah sesuai dengan perkembangan dan kebutuhan masyarakat. Hal ini dibuktikan dengan adanya kemajuan ataupun perkembangan dari objek Praperadilan. Sejalan dengan hal tersebut paradigmatik yang menempatkan manusia di atas hukum, karena hukum untuk manusia, membawa konsekuensi pada cara berhukum, bahwa teks peraturan bukan merupakan sesuatu yang final dan harus disakralkan atau dikultuskan. Cara berhukum yang progresif menolak keterikatan pada teks peraturan secara kaku, melainkan menyerahkannya pada perilaku manusianya, tentu saja dalam hal ini adalah perilaku yang baik. Apabila kepentingan manusia dan kemanusiaan menghendaki, maka teks peraturan sesungguhnya bisa diabaikan. ${ }^{13}$

Melalui Amar putusan Mahkamah Konstitusi Nomor 21/PUU-XII/2014, objek Praperadilan telah diperluas dengan kewenangan dalam menentukan sah atau tidaknya Penetapan Tersangka, Penggeledahan dan Penyitaan. Amar Putusan Mahkamah Konstitusi Nomor 21/PUU-XII/2014 menyatakan bahwa Pasal 77 huruf a KUHAP bertentangan dengan Undang-Undang Dasar Negara Republik Indonesia Tahun 1945 sepanjang tidak dimaknai termasuk penetapan tersangka, penggeledahan, dan penyitaan. Selanjutnya Pasal 77 huruf a KUHAP tidak mempunyai kekuatan hukum mengikat sepanjang tidak dimaknai termasuk penetapan tersangka, penggeledahan dan penyitaan sebagai bagian dari perluasan objek Praperadilan.

Berdasarkan penjelasan di atas, bahwa setelah diperluasnya objek Praperadilan melalui Putusan Mahkamah Konstitusi Nomor 21/PUU-XII/2014, dengan sendirinya merubah tatanan ataupun aturan mengenai kewenangan Praperadilan yang sebelumnya telah diatur dalam KUHAP, dan hal ini tentunya akan sangat berpengaruh terhadap pembaharuan dari KUHAP itu sendiri.

Berdasarkan penjelasan di atas, terlihat adanya perhatian yang lebih ditonjolkan pada dihormatinya hak-hak asasi manusia yang dicantumkan dalam KUHAP, sehingga dapat diatrik kesimpulan bahwa sah atau tidaknya penetapan

12 Agus Santoso, Hukum, Moral \% Keadilan Sebuah Kajian Filsafat Hukum, Prenada Media, Jakarta, 2014, hlm. 61.

13 M.Zulfa Aulia, Hukum Progresif dari Satjipto Raharjo: Riwayat, Urgensi dan Relevansi, Undang Jurnal Hukum, Volume 1 Nomor 1, 2018, hlm 167. 
status tersangka menjadi objek praperadilan dengan landasan bahwa mungkin terjadi perbuatan atau sewenang-wenang oleh Penyidik yang bertentangan dengan undang-undang dalam proses penyidikan dan juga menetapkan status tersangka terhadap seseorang dinilai sebagai salah satu bentuk cara menghormati hak asasi seseorang. Namun disisi lain, kita tidak boleh menutup mata bahwa dalam proses penegakan hukum sesuai dengan Teori Sistem Peradilan Pidana dimana setiap aparat penegak hukum telah bekerja sama dengan satu tujuan yaitu menekan angka kejahatan dengan meminimalisir kesalahan dalam proses atau pemeriksaan suatu tindak pidana yang terjadi. Oleh karena itu, hal yang seharusnya dilakukan adalah meningkatkan kinerja dan juga pengawasan terhadap para aparat penegak hukum terutama penyidik dalam hal menetapkan status tersangka pada seseorang, dan apabila kemudian hari ditemukan kesalahan terkait dengan penetapan status tersangka terhadap seseorang maka jalan keluarnya bukanlah melalui Praperadilan melainkan dengan penghentian penyidikan.

Disamping itu, mungkin saja terjadi bahwa apabila dilakukannya penghentian penyidikan, maka akan terjadi suatu keresahan dalam masyarakat, maka pihak penyidik sendiri dapat memohon diperiksa penghentian penyidikannya oleh Praperadilan, dengan demikian walaupun diputuskan bahwa penghentian penyidik dianggap sah, maka hal tersebut tetap dapat menjadi suatu kepastian hukum bagi masyarakat. Berdasarkan uraian diatas, disimpulkan bahwa sah atau tidaknya penetapan status tersangka seharusnya tidak perlu menjadi perluasan dari objek praperadilan. Karena pada dasarnya, dalam hal menetapkan status tersangka pada seseorang tentunya para aparat penegak hukum telah melaksanakan tugas dan fungsinya sesuai dengan prosedur yang berlaku dan bekerja secara profesional serta menjunjung tinggi hak asasi manusia, dan penulis meyakini bahwa KUHAP telah menjamin hak-hak tersebut dalam proses penyidikan yang dilangsungkan oleh para aparat penegak hukum dalam menegakkan hukum. Kemudian hal terpenting yang harus dilakukan terhadap upaya paksa bukanlah memperluas objek yang telah ada, melainkan penggunaan ataupun pelaksanaan upaya paksa inilah yang harus dikontrol secara ketat, baik syarat-syarat maupun prosedur pelaksanaannya guna menghindari terjadinya kesalahan. 
2. Akibat dari Perluasan Objek Praperadilan terhadap Penetapan Status Tersangka Tindak Pidana Korupsi oleh Komisi Pemberantasan Korupsi

Penetapan status seseorang menjadi tersangka harus dilakukan sehati-hati mungkin agar tidak terjadi kesesatan mengenai pelaku tindak pidana itu sendiri (error in persona). Penetapan status tersangka harus berdasarkan bukti permulaan yang cukup yang telah dikumpulkan dalam proses penyidikan. Penetapan status tersangka merupakan hasil akhir dari proses penyidikan, adapun definisi dari penyidikan yang diatur oleh Pasal 1 butir 2 KUHAP adalah sebagai berikut:

Penyidikan adalah serangkaian tindakan penyidik dalam hal dan menurut cara yang diatur dalam undang-undang ini untuk mencari serta mengumpulkan bukti yang dengan bukti itu membuat terang tentang tindak pidana yang terjadi dan guna menemukan tersangkanya.

Dengan demikian, penulis menyimpulkan bahwa penetapan status tersangka pada seseorang merupakan akhir dari proses penyidikan yang sebelumnya telah dilakukan oleh penyidik berdasarkan bukti-bukti permulaan yang berhasil dikumpulkan untuk selanjutnya memperoleh kejelasan akan suatu tindak pidana yang terjadi.

Terkait dengan penetapan status tersangka terhadap seseorang, berdasarkan Amar Putusan Mahkamah Konstitusi Nomor 21/PUU-XII/2014 terkait pengujian Undang-Undang Nomor 8 Tahun 1981 Tentang Hukum Acara Pidana terhadap Undang-Undang Dasar Negara Republik Indonesia Tahun 1945, terdapat wewenang tambahan yang diberikan oleh undang-undang kepada Praperadilan lewat Putusan Mahkamah Konstitusi ini, antara lain memeriksa sah atau tidaknya penetapan tersangka; memeriksa sah atau tidaknya penggeledahan; dan memeriksa sah atau tidaknya penyitaan.

Dengan munculnya Putusan Mahkamah Konstitusi ini, maka objek Praperadilan di Indonesia yang sebelumnya diatur dalam Pasal 1 butir 10 juncto Pasal 77 KUHAP, dinyatakan tidak berlaku lagi sepanjang tidak dimaknai dengan sah atau tidaknya penetapan status tersangka, penggeledahan dan penyitaan.

Lembaga praperadilan bukan merupakan suatu badan tersendiri, tetapi hanya suatu wewenang saja dari Pengadilan Negeri. Pemberian wewenang ini bertujuan untuk menegakkan hukum dan keadilan secara sederhana, cepat dan murah dalam rangka memulihkan harkat/martabat, kemampuan/kedudukan serta mengganti kerugian terhadap korban yang merasa dirugikan. Dengan 
adanya lembaga praperadilan dijamin bahwa seseorang tidak ditangkap atau ditahan tanpa alasan yang sah. Penangkapan hanya dilakukan atas dasar dugaan yang kuat dengan landasan bukti permulaan yang cukup. Sedangkan ketentuan tentang bukti permulaan ini diserahkan penilaiannya kepada penyidik. Hal ini membuka kemungkinan sebagai alasan pengajuan pemeriksaan praperadilan.

Jika berbicara mengenai perluasan objek Praperadilan atas penetapan status tersangka, tentunya juga termasuk didalamnya penetapan status tersangka korupsi. Perbuatan tindak pidana korupsi merupakan pelanggaran terhadap hak-hak sosial dan hak-hak ekonomi masyarakat, sehingga tindak pidana korupsi tidak dapat lagi digolongkan sebagai kejahatan biasa (ordinarycrimes) melainkan telah menjadi kejahatan luar biasa (extra ordinary crimes). Sehingga dalam upaya pemberantasannya tidak lagi dapat dilakukan secara biasa, tetapi harus dengan cara-cara yang juga luar biasa (extra-ordinary enforcement).

Komisi Pemberantasan Korupsi (KPK) merupakan lembaga yang berwenang untuk menangani Tindak Pidana Korupsi lewat amanah UndangUndang Nomor 30 Tahun 2002 Tentang Komisi Pemberantasan Tindak Pidana Korupsi. Pasal 43 ayat (2) Undang-Undang Nomor 31 Tahun 1999 menyebutkan bahwa "Komisi Pemberantasan Korupsi mempunyai tugas dan wewenang a. Melakukan Koordinasi dan Supervisi; b. Melakukan Penyelidikan; c. Melakukan Penyidikan; dan d. Melakukan Penuntutan."

Namun hal terpenting yang harus diingat bahwa dalam pelaksanaan tugasnya untuk melakukan Penyelidikan, Penyidikan dan Penuntutan tindak pidana korupsi, kewenangan Komisi Pemberantasan Korupsi dibatasi hanya pada tindak pidana korupsi yang:

a. Melibatkan aparat penegak hukum, penyelenggara negara, dan orang lain yang ada kaitannya dengan tindak pidana korupsi yang dilakukan oleh aparat penegak hukum atau penyelenggara negara;

b. Mendapat perhatian yang meresahkan masyarakat; dan/atau

c. Menyangkut kerugian negara paling sedikit Rp. 1.000.000.000,00 (satu milyar rupiah).

Berbeda dengan tindak pidana umum yang data awal diperoleh dari Laporan atau Pengaduan, Tindak Pidana Korupsi data awalnya antara lain diperoleh dari Menteri/Irjen/Banwasda/Irwilprop; Badan Pengawas Keuangan dan Pembangunan (BPKP); Dewan Perwakilan Rakyat (DPR) yang merupakan hasil audit BPK; dan Aparat Intelijen. Setelah adanya data awal, maka diterbitkanlah Surat Perintah Penyelidikan untuk mengetahui ada atau tidaknya 
tindak pidana korupsi yang terjadi, dengan didasarkan pada bukti permulaan yang cukup. Tetapi dengan diterbitkannya Surat Perintah Penyelidikan, banyak orang berprasangka bahwa telah terjadi tindak pidana korupsi. Menurut penulis, hal demikian merupakan suatu kekeliruan berfikir karena ada kalanya tidak ditemukan bukti permulaan yang cukup, sementara jika ditemukan bukti permulaan yang cukup, maka barulah tahap penyelidikan ditingkatkan ke tahap

Penyidikan dan selanjutnya diterbitkan Surat Perintah Penyidikan.

Pasal 44 Undang-Undang KPK merumuskan bahwa:

(1) Jika di dalam melakukan penyelidikan penyelidik menemukan bukti permulaan yang cukup adanya dugaan tindak pidana korupsi, maka dalam waktu paling lambat 7 (tujuh) hari kerja terhitung sejak tanggal ditemukannya bukti permulaan yang cukup tersebut, penyelidik melaporkan kepada Komisi Pemberantasan Korupsi;

(2) Bukti permulaan yang cukup dianggap telah ada apabila telah ditemukan sekurang-kurangnya 2 (dua) alat bukti, termasuk dan tidak terbatas pada informasi atau data yang diucapkan, dikirim, diterima atau disimpan baik secara biasa maupun elektronik atau optik;

(3) Dalam hal penyelidik melakukan tugasnya tidak menemukan bukti permulaan yang cukup sebagaimana dimaksud pada ayat (1), penyelidik melaporkan kepada Komisi Pemberantasan Korupsi dan Komisi Pemberantasan Korupsi menghentikan penyelidikan;

(4) Dalam hal Komisi Pemberantasan Korupsi berpendapat bahwa perkara tersebut diteruskan, Komisi Pemberantasan Korupsi melaksanakan penyidikan sendiri dan dapat melimpahkan perkara tersebut kepada penyidik kepolisian atau kejaksaan;

(5) Dalam hal penyelidikan dilimpahkan kepada kepolisian atau ke kejaksaan sebagaimana dimaksud pada ayat (4), kepolisian dan kejaksaan wajib melaksanakan koordinasi dan melaporkan perkembangan penyidikan kepada Komisi Pemberantasan Korupsi.

Berdasarkan pasal di atas, disimpulkan bahwa hasil dari proses penyidikan merupakan penentu penetapan status tersangka terhadap orang yang diduga melakukan tindak pidana korupsi yang merugikan keuangan negara minimal satu milyar rupiah, yang mana penetapannya dilakukan oleh penyidik Komisi Pemberantasan Korupsi (KPK).

Beranjak dari bagaimana pelaksanaan proses penyidikan yang berbuah pada penetapan status tersangka tindak pidana korupsi, terkait perluasan objek Praperadilan atas sah atau tidaknya Penetapan Status Tersangka, terdapat beberapa kasus gugatan Praperadilan yang terjadi di Indonesia, salah satu kasus yang masih segar dalam ingatan kita pada 26 Januari 2015 lalu, terkait dengan pengajuan gugatan Praperadilan oleh Komisaris Jenderal Polisi Budi Gunawan terhadap Komisi Pemberantasan Korupsi atas Penetapannya sebagai tersangka dalam kasus Gratifikasi yang kemudian permohonannya dikabulkan oleh Hakim Tunggal Praperadilan Sarpin Rizaldi, yang berakibat pada Pembatalan Status 
Tersangka pada Budi Gunawan melalui Putusan Praperadilan Nomor 04/Pid.Prap/2015/PN.Jak.Sel.

Budi Gunawan mengatakan bahwa KPK melakukan penggeledahan, penyitaan maupun penetapan sebagai Tersangka tanpa dasar hukum. Sehingga Budi Gunawan mengajukan praperadilan ke Pengadilan Negeri Jakarta Selatan. Di dalam gugatannya, Budi Gunawan memohon agar hakim menyatakan penetapan status tersangkanya tidak sah. Budi Gunawan juga merujuk pada putusan pengadilan pada kasus Chevron dengan nomor 38/Pid.Prap/2012/PN.Jak.Sel, dimana hakim praperadilan membatalkan status tersangka saudara Bachtiar yang merupakan tersangka pada kasus Chevron. Sampai saat gugatannya diputus oleh Hakim tunggal Praperadilan, kasus ini terus menuai kritik pengamat dan publik/masyarakat, karena dianggap mengacaukan penegakan hukum.

Adapun beberapa pertimbangan hakim Sarpin dalam memutuskan bahwa penetapan status tersangka oleh KPK kepada Budi Gunawan adalah tidak sah adalah sebagai berikut:

Menimbang bahwa saat Budi Gunawan menjadi Kepala Biro Pembinaan Karir, masyarakat tidak mengenal pemohon. Masyarakat baru mengenal pemohon sejak pemohon ditetapkan sebagai calon Kapolri oleh Presiden. Dan sehari setelah itu, pemohon ditetapkan sebagai tersangka oleh KPK sehingga klasifikasi mendapat perhatian masyarakat sebagaimana yang dimaksud dengan Pasal 11 huruf b UU KPK tidak terpenuhi. Selanjutnya bahwa Pasal 11 huruf b UU KPK menyebutkan bahwa subjek hukum tindak pidana korupsi yang dijadikan kewenangan KPK adalah orangorang yang perbuatannya menyebabkan kerugian keuangan negara paling sedikit Rp. 1 Miliar. Selanjutnya menimbang bahwa bukti berupa surat penyidikan, nomor sprindik 03/01/02/2015 tanggal 12 Januari 2015, dilampiri register penomoran sprindik disekretariat penyidikan, disebutkan bahwa pemohon diduga melakukan tindak pidana korupsi secara bersama-sama menerima hadiah, menimbang bahwa perbuatan menerima hadiah atau janji, tidak dikaitkan dengan timbulnya kerugian terhadap negara. Karena perbuatan tersebut berkaitan dengan penyalahgunaan kekuasaan dan kewenangan, sehingga dengan demikian apa yang diduga dilakukan oleh pemohon tidak menyebabkan kerugian negara, sehingga kualifikasi dalam Pasal KPK tidak terbukti. ${ }^{14}$

Berdasarkan isi putusan praperadilan Pengadilan Negeri Jakarta Selatan yang mengabulkan permohonan praperadilan dari pemohon untuk sebagian, tidak berdasarkan aturan yang semestinya. Hal ini dikuatkan karena berdasarkan pengaturan pasal 77 KUHAP pada saat putusan dijatuhkan oleh Hakim tunggal, sah atau tidaknya penetapan status Tersangka bukan merupakan

14 Putusan Praperadilan Nomor 04/Pid.Prap/2015/PN.Jkt.Sel hal. 229-244. 
objek dari praperadilan. Namun yang tidak kalah penting adalah putusan tersebut merupakan sebuah penemuan hukum yang dilakukan oleh hakim Sarpin Rizaldi. Hal tersebut dapat dikatakan merupakan sebuah terobosan hukum demi memenuhi kebutuhan hukum yang ada dalam masyarakat

Berdasarkan kasus di atas, disimpulkan bahwa Hakim praperadilan telah melebihi kewenangannya dalam memberikan putusan, karena pada saat hakim praperadilan memberikan putusan, kewenangan untuk mengisi kekosongan hukum acara atau membuat pengaturan tentang penyelesaian suatu persoalan belum diatur dalam hukum acara termasuk menafsirkan pelaksanaan hukum acara itu ada di Mahkamah Agung, sehingga tidak dapat dipungkiri bahwa putusan tersebut menjadi kontroversional setelah hakim Sarpin menyatakan bahwa ketidak absahan penetapan status tersangka oleh KPK terhadap Budi Gunawan, karena telah jelas diatur dalam Pasal 77 KUHAP yang didalamnya tidak mencantumkan sah atau tidaknya penetapan status tersangka sebagai objek Praperadilan. Sehingga hal ini tentunya tidak sesuai dengan nilai yang seharusnya dilakukan oleh hakim pengadilan sebagai bentuk dari implementasi teori Sistem Peradilan Pidana yang menghendaki pemeriksaan di sidang pengadilan termasuk dalam hal ini pemeriksaan sidang Praperadilan yang benarbenar objektif guna memberikan kepastian hukum.

Sebelum diputusnya permohonan praperadilan Budi Gunawan oleh Hakim Sarpin Rizaldi, sebenarnya telah ada permohonan uji materil (judicial review) mengenai penetapan status tersangka ke Mahkamah Konstitusi (MK). Permohonan tersebut tercatat dalam Buku Registrasi Perkara Konstitusi dengan nomor 21/PUU-XII/2014 pada tanggal 26 Februari 2014. Namun, permohonan tersebut baru diputuskan dan dipublikasikan pada Sidang Pleno Mahkamah Konstitusi terbuka untuk umum hari Selasa, 28 April 2015.

Bachtiar Abdul Fatah merupakan mantan General Manager SLS Operation di PT Chevron Pacific Indonesia. Kejaksaan Agung menetapkannya sebagai tersangka karena diduga melakukan tindak pidana korupsi bioremediasi PT Chevron Pacific Indonesia. Tidak terima dirinya ditetapkan sebagai tersangka, Bachtiar mengajukan permohonan Praperadilan ke Pengadilan Negeri Jakarta Selatan. Permohonan Praperadilan tersebut akhirnya dikabulkan oleh Hakim tunggal Suko Harsono. Namun, pada tanggal 21 Maret 2013 Badan Pengawas MA mengeluarkan surat yang pada pokoknya menerangkan bahwa Hakim Suko Harsono terbukti melanggar kode etik karena telah memperluas objek Praperadilan. Dengan surat ini, Kejaksaan Agung melanjutkan proses perkara 
Bachtiar dan dilimpahkan ke Pengadilan. Alhasil perkara bioremediasi Bachtiar tetap disidangkan.

Hingga akhirnya pada tanggal 17 Februari 2014 Bachtiar Abdul Fatah mengajukan permohonan pengujian Undang-Undang Nomor 8 Tahun 1981 tentang Hukum Acara Pidana (KUHAP) terhadap Undang-Undang Dasar ke Mahkamah Konstitusi, yang permohonannya antara lain:

1. Mengabulkan permohonan Pemohon untuk seluruhnya;

2. Menyatakan frasa "dan guna menemukan tersangkanya" dalam Pasal 1 angka (2) KUHAP bertentangan dengan UUD 1945 secara bersyarat (conditionally unconstitutional) dan tidak mempunyai kekuatan hukum mengikat sepanjang tidak dimaknai "dan berdasarkan hasil penyidikan tersebut untuk kemudian dapat menenmukan tersangkanya";

3. Menyatakan frasa "bukti permulaan" dalam Pasal 1 angka (14) KUHAP bertentangan dengan UUD 1945 secara bersyarat (conditionally unconstitutional) dan tidak mempunyai kekuatan hukum mengikat sepanjang tidak dimaknai "sekurang-kurangnya 2 (dua) alat bukti";

4. Menyatakan frasa "bukti permulaan yang cukup" dalam Pasal 17 KUHAP bertentangan dengan UUD 1945 secara bersyarat (conditionally unconstitutional) dan tidak mempunyai kekuatan hukum mengikat sepanjang tidak dimaknai "sekurang-kurangnya 2 (dua) alat bukti";

5. Menyatakan frasa "melakukan tindak pidana" dan frasa "dalam hal adanya keadaan yang menimbulkan kekhawatiran bahwa tersangka atau terdakwa" dalam Pasal 21 ayat (1) KUHAP bertentangan dengan UUD 1945 dan tidak mempunyai kekuatan hukum mengikat;

6. Menyatakan Pasal 77 huruf (a) KUHAP bertentangan dengan UUD 1945 secara bersyarat (conditionally unconstitutional) dan tidak mempunyai kekuatan hukum mengikat sepanjang tidak dimaknai mencakup sah atau tidaknya penetapan tersangka, penggeledahan, penyitaan, pemeriksaan surat;

7. Menyatakan frasa "sebaliknya dalam hal tidak diterima atau hakim berpendapat hal tersebut baru dapat diputus setelah selesai pemeriksaan maka sidang dilanjutkan." dalam Pasal 156 ayat (2) KUHAP bertentangan dengan UUD 1945 dan tidak mempunyai kekuatan hukum mengikat;

8. Memerintahkan pemuatan putusan ini dalam Berita Negara Republik Indonesia sebagaimana mestinya.

Berdasarkan Putusan Nomor 21/PUU-XII/2014, walaupun permohonan Pemohan dikabulkan hanya sebagian, namun telah terjadi perubahan yang fundamental terhadap objek praperadilan. Mahkamah Konstitusi mengabulkan sebagian pengujian Undang-Undang Nomor 8 Tahun 1981 tentang Hukum Acara Pidana (KUHAP) yang diajukan oleh terpidana kasus korupsi bioremediasi fiktif PT. Chevron Pasific Indonesia, Bachtiar Abdul Fatah.

Setelah banyaknya kontroversi yang terjadi akibat perluasan objek praperadilan ini, akhirnya kontroversi itupun dilegitimasi oleh Mahkamah Konstitusi melalui Putusan Mahkamah Konstitusi Nomor 21/PUU-XII/2014 yang 
menjadikan Penetapan Status Tersangka sebagai salah satu perluasan objek praperadilan disamping sah atau tidaknya penggeledahan dan penyitaan.

Dengan dikabulkannya permohonan pemohon untuk sebagian, dapat disimpulkan bahwa telah terjadi perubahan yang bersifat fundamental mengenai kewenangan Praperadilan yang diatur di dalam Undang-Undang Nomor 8 Tahun 1981 tentang Kitab Undang-Undang Hukum Acara Pidana, dimana dengan kata lain Mahkamah Konstitusi menyetujui bahwa Kitab Undang-Undang Hukum Acara Pidana tersebut telah bertentangan dengan Undang-Undang Dasar Negara Republik Indonesia Tahun 1945.

Pada bulan September tahun 2017 lalu, putusan serupa yang tidak kalah kontroversial adalah penetapan status tersangka kasus Dugaan Tindak Pidana Korupsi Pengadaan Paket Penerapan KTP berbasis Nomor Induk Kependudukan secara nasional (KTP-EI) terhadap Setya Novanto melalui Putusan Praperadilan Nomor 97/Pid.Prap/2017/PN.Jkt.Sel yang mengabulkan dan membatalkan status tersangka pada Ketua DPR tersebut pada hari Jumat tanggal 29 September 2017 lalu.

Munculnya putusan praperadilan Setya Novanto menimbulkan fenomena tersendiri dikalangan masyarakat, karena dinilai banyaknya kejanggalan yang terjadi pada putusan praperadilan tersebut. Lembaga pegiat antikorupsi ICW menilai bahwa sejak awal sudah ada beberapa kejanggalan dalam proses praperadilan terkait penetapan tersangka Setya Novanto tersebut. Salah satunya, adalah saksi-saksi ahli yang diajukan oleh KPK dikesampingkan oleh hakim, yang hanya mempertimbangkan yang diajukan oleh tersangka, selanjutnya Hakim menolak untuk memutar bukti rekaman keterlibatan Setya Novanto dalam kasus korupsi KTP-Elektronik, Kejanggalan lainnya adalah saat Hakim menunda mendengar keterangan ahli dari KPK pada 27 September 2017 lalu, Hakim kemudian mengabaikan permohonan intervensi dengan alasan gugatan tersebut belum terdaftar di dalam sistem informasi pencatatan perkara dan di sisi lain, Hakim Cepi Iskandar justru membuka ruang pengujian materi perkara dengan menolak eksepsi KPK terkait dengan pembuktian keterpenuhan unsur pada Pasal 2 ayat (1) UU Tipikor, yang menjadi salah satu dalil permohonan Praperadilan Setya Novanto. Padahal, pembuktian keterpenuhan unsur Pasal 2 ayat (1) UU Tipikor sudah masuk pada pembuktian pokok perkara, dan tidak sepatutnya disidangkan lewat mekanisme praperadilan. Selain itu, Hakim juga mempertimbangkan mengenai besaran kerugian keuangan negara, maka pertimbangan dalam hal inilah yang tidak seharusnya dipertimbangkan dalam 
sidang praperadilan, sebab yang demikian itu sudah memasuki pemeriksaan pokok perkara. Dalam kasus ini, hakim tidak melanggar mekanisme acara praperadilan, akan tetapi yang dilanggar oleh hakim praperadilan adalah dalam perkara aquo adalah asas nebis in idem. Hakim tersebut mungkin lupa dengan asas ini atau mungkin sengaja agar pemohon tidak dapat dituntut dua kali dalam perkara yang sama.

Berdasarkan penjelasan kasus di atas, dapat disimpulkan bahwa perluasan objek Praperadilan terkait Penetapan Status Tersangka merupakan salah satu bentuk upaya perlindungan terhadap hak asasi manusia, namun disisi lain seperti dalam kasus penetapan status tersangka terhadap Budi Gunawan dan Setya Novanto membuktikan bahwa proses pengajuan gugatan ke lembaga Praperadilan terkait sah atau tidaknya penetapan status tersangka telah menghambat proses peradilan, karena pengajuan gugatan Praperadilan yang dilakukan sebelum tahap penuntutan atau Pra-penuntutan, sehingga proses pengajuan gugatan praperadilan ini menghambat proses penuntutun sebagai tahapan penegakan hukum yang seharusnya dilaksanakan secara cepat, sederhana dan biaya ringan sesuai dengan asas peradilan yang sebagaimana mestinya guna memberikan kepastian hukum. Hal yang tidak dapat dihindari bahwa dalam beberapa kasus yang terjadi, hakim praperadilan justru melakukan pemeriksaan terkait materi pokok perkara yang seharusnya bukanlah menjadi kewenangan yang berhak diuji oleh lembaga praperadilan, melainkan harus dibuktikan melalui proses persidangan di Pengadilan, hal ini berdampak pada para tersangka tindak pidana korupsi yang kemudian tidak serta merta menjadikan Praperadilan sebagai tempat untuk mempertahankan dan melindungi hak-haknya tapi justru menjadikan Praperadilan sebagai sarana untuk melepaskan diri dari jerat hukuman. Oleh karena itu, hal terpenting yang harus dilakukan adalah dengan meningkatkan kualitas kerja dari seluruh elemen penegak hukum agar dalam menetapkan seseorang sebagai tersangka dilakukan dengan hati-hati dan mengedepankan aturan yang berlaku, kemudian apabila dikemudian hari ditemukan kesalahan yang dilakukan oleh aparat penegak hukum dalam hal ini penyidik pada saat menetapkan status tersangka pada seseorang, hal yang harus dilakukan adalah dengan menerbitkan Surat Pemberitahuan Penghentian Penyidikan (SP3), karena jika dikaitkan dengan teori Perlindungan hukum dalam hal ini perlindungan terhadap hak tersangka, Praperadilan tentu sangat dibutuhkan sebagai lembaga dimana tersangka dapat melindungi hak-haknya atas kesalahan yang mungkin dilakukan oleh penyidik. 
Berdasarkan Putusan Mahkamah Konstitusi Nomor 21/PUU-XII/2014, kedepannya dalam hal pengajuan gugatan praperadilan terkait penetapan tersangka harus dilaksanakan sesuai prosedur yang berkeadilan, memberikan kepastian hukum, dan kemanfaatan sehingga terciptalah sistem peradilan pidana yang baik dalam hal penyelesaian tindak pidana korupsi.

\section{Simpulan}

Dari uraian yang sebagaimana yang telah dipaparkan di atas, maka disimpulkan bahwa, akibat dari Perluasan Objek Praperadilan berdasarkan Putusan Mahkamah Konstitusi Nomor 21/PUU-XII/2014 terkait pengujian UndangUndang Nomor 8 Tahun 1981 Tentang Hukum Acara Pidana terhadap UndangUndang Dasar Negara Republik Indonesia Tahun 1945 adalah Pasal 77 KUHAP tidak berlaku sepanjang tidak dimaknai dengan Sah atau tidaknya Penetapan Status Tersangka, Penggeledahan dan Penyitaan. Selain itu akibat perluasan Objek Praperadilan terkait Penetapan Status Tersangka merupakan salah satu bentuk upaya perlindungan terhadap hak asasi manusia, namun disisi lain seperti dalam kasus penetapan status tersangka terhadap Budi Gunawan dan Setya Novanto membuktikan bahwa proses pengajuan gugatan ke lembaga Praperadilan terkait sah atau tidaknya penetapan status tersangka telah menghambat proses peradilan, karena pengajuan gugatan Praperadilan yang dilakukan sebelum tahap penuntutan atau Pra-penuntutan, sehingga proses pengajuan gugatan praperadilan ini menghambat proses penuntutun sebagai tahapan penegakan hukum yang seharusnya dilaksanakan secara cepat, sederhana dan biaya ringan sesuai dengan asas peradilan yang sebagaimana mestinya guna memberikan kepastian hukum.

\section{DAFTAR PUSTAKA}

\section{Dokumen Hukum:}

Kepolisisan Negara Republik Indonesia. Peraturan Kepala Tentang Pengawasan dan Pengendalian Penanganan Perkara Pidana di Lingkungan Kepolisian Negara Republik Indonesia, Nomor 12 Tahun 2009.

Mahkamah Agung. Surat Edaran Tentang Pemberlakuan Rumusan Hasil Rapat Pleno Kamar Mahkamah Agung Tahun 2016 Sebagai Pedoman Pelaksanaan Tugas Bagi Pengadilan, Nomor 4 Tahun 2016.

Mahkamah Konstitusi. Putusan Nomor 25/PUU-XIV/2016.

Mahkamah Konstitusi. Putusan Nomor 21/PUU-XII/2014.

Pengadilan Negeri Jakarta Selatan. Putusan Praperadilan Nomor 04/Pid.Prap/2015/PN.Jkt.Sel.

Pengadilan Negeri Jakarta Selatan. Putusan Praperadilan Nomor 97/Pid.Prap/2017/PN.Jkt.Sel.

Republik Indonesia. Undang-Undang Tentang Komisi Pemberantasan Korupsi, Nomor 30 Tahun 2002 
Republik Indonesia. Undang-Undang Tentang Pemberantasan Tindak Pidana Korupsi yang telah diubah dengan Undang-Undang Nomor 20 Tahun 2001 Tentang Perubahan atas Undang-Undang Nomor 31 Tahun 1999 Tentang Pemberantasan Tindak Pidana Korupsi, Nomor 31 Tahun 1999

Republik Indonesia. Undang-Undang Tentang Kitab Undang-Undang Hukum Acara Pidana, Nomor 8 Tahun 1981

\section{Buku:}

Ali, Mahrus. Asas, Teori dan Praktek Hukum Pidana Korupsi. UII Press, Yogyakarta. 2013.

Ali, Zainuddin. Metode Penelitian Hukum. Sinar Grafika, Jakarta. 2013.

Asshiddiqie, Jimly. Perkembangan \& Konsolidasi Lembaga Negara Pasca Reformasi. Sinar Grafika, Jakarta. 2012.

Chazawi, Adami. Hukum Pidana Korupsi di Indonesia (Edisi Revisi), PT. Rajagrafindo. Persada, Jakarta. 2016.

Djaja, Ermansyah. Memberantas Korupsi Bersama KPK. Sinar Grafika, Jakarta. 2008.

Fahrojih, Ikhwan. Hukum Acara Pidana Korupsi. Setara Press, Malang. 2016.

Hamzah, Andi. Hukum Acara Pidana Indonesia Edisi Revisi. Sinar Grafika, Jakarta. 2004.

Harahap, M. Yahya. Hukum Acara Perdata: Tentang Gugatan, Persidangan, Penyitaan, Pembuktian dan Putusan Pengadilan. Sinar Grafika, Jakarta. 2016.

Hartanti, Evi. Tindak Pidana Korupsi. Edisi Kedua. Sinar Grafika, Jakarta. 2014.

Komisi Pemberantasan Korupsi. Buku Saku Untuk Memahami Tindak Pidana Korupsi. KPK. Jakarta. 2006.

Loqman, Leobby. Pra-Peradilan di Indonesia. Ghalia Indonesia, Jakarta. 1987.

Nasution, Bahder Johan. Metode Penelitian Hukum. CV. Mandar Maju, Bandung. 2008.

Pembahasan Permasalahan dan Penerapan KUHAP Pemeriksaan Sidang Pengadilan, Banding, Kasasi dan Peninjauan Kembali. Edisi Kedua. Sinar Grafika Jakarta. 2012.

Pemberantasan Korupsi: Melalui Hukum Pidana Nasional dan Internasional. PT. Raja Grafindo Persada, Jakarta. 2007.

Rahardjo, Satjipto. Hukum Progresif, Sebuah Sintesa Hukum Indonesia. Gentaa Publishing, Yogyakarta, 2009.

Rosikah, Chatrina Darul dan Listianingsih, Dessy Marliani. Pendidikan Antikorupsi Kajian Antikorupsi Teori dan Praktik. Sinar Grafika, Jakarta. 2016.

Rudyat, Charlie. Kamus Hukum. Pustaka Mahardika, Jakarta. 2013.

Saleh, Imam Anshori. Korupsi, Terorisme, dan Narkoba (Upaya Melawan Kejahatanan Luar Biasa yang Sistematis). Setara Press, Malang. 2017. 
Santoso, Agus. Hukum, Moral \% Keadilan Sebuah Kajian Filsafat Hukum. Prenada Media, Jakarta 2014.

Sasangka, Hari. Penyidikan Penahanan Penuntutan Dan Praperadilan Cetakan pertama. CV. Mandar Maju, Bandung. 2007.

Simanjuntak, Nikolas. Acara Pidana Indonesia dalam Sirkus Hukum, Ghalia Indonesia, Jakarta. 2009.

Soekanto, Soerjono dan Mamudji, Sri. Penelitian Hukum Normatif, Suatu Tinjauan Singkat. Rajawali, Jakarta. 1990.

Soekanto, Soerjono. Faktor-Faktor yang Mempengaruhi Penegakan Hukum. PT Raja Grafindo Persada, Jakarta. 2010.

Suratman \& Dillah, Philips. Metode Penelitian Hukum. Alfabeta, Bandung. 2014.

Yamin, Muhammad. Tindak Pidana Khusus. Pustaka Setia, Bandung. 2012.

Yuspar. Penegakan Hukum Responsif Terobosan Kejaksaan Menyelesaikan Tunggakan Perkara Korupsi Untuk Kepastian Hukum. Genta Publishing, Yogyakarta. 2017.

\section{Jurnal:}

Andy Effendy, Ahmad. "Tinjauan Yuridis Mengenai Penetapan Status Tersangka sebagai Objek dalam Praperadilan oleh Mahkamah Konstitusi" Jurnal pada Fakultas Hukum Universitas Narotama, Surabaya: 2015.

Aulia, M. Zulfa, Hukum Progresif dari Satjipto Rahardjo: Riwayat, Urgensi dan Relevansi. Undang Jurnal Hukum, Fakultas Hukum Universitas Jambi, 2018.

Farezha, Wanda Rara, Edy Rifa'I dan Gunawan Jatmiko. “Abstrak Analisis Putusan Hakim Praperadilan dalam Perkara Tindak Pidana Korupsi (Studi Putusan Praperadilan Nomor 14/Pid.Pra/2016/PN.Tjk." Jurnal Pada Fakultas Hukum Universitas Lampung: 2017.

Kulsum, Umi. "Kewenangan Komisi Pemberantasann Korupsi (KPK) dalam Melakukan Pemberantasan Tindak Pidana Korupsi." Jurnal Jure Humano, Volume $1: 2009$.

M. Hadjon, Philipus. "Pengkajian Ilmu Hukum Dogmatik (Normatif), dalam "Yuridikal" Jurnal Pada Hukum Universitas Airlangga Surabaya: 1994.

Morgan Tarigan, Randa. "Sah Tidaknya Penetapan Status Tersangka oleh Komisi Pemberantasan Korupsi (KPK) yang diajukan sebagai Alasan Praperadilan ditinjau dari Hukum Acara Pidana di Indonesia (Studi Terhadap Putusan Nomor: Departemen Hukum Pidana Fakultas Hukum Universitas Sumatera Utara: 2015.

Riyanto, Sigid. "Perlindungan Hukum Tersangka Dalam Proses Penyidikan Tindak Pidana Umum.” Laporan Hasil Penelitian pada Fakultas Hukum UGM, Yogyakarta: 2001.

\section{Internet:}

http://www.mahkamahkonstitusi.go.id/index.php?page=web.Berita\&id=10796

https://m.hukumonline.com/berita/baca/lt5888f5b5bb039/begini-alasan-mk-ubah delik-tipikor 
PAMPAS: Journal of Criminal Law Vol. 1, No. 2

https://www.google.co.id/amp/amp.kompas.com/nasioanal/read/2015/01/21/1413 0431/Menyandera.dengan.status.tersangka

https://www.google.co.id/amp/s/www.voaindonesia.com/amp/3692750.html 